\title{
Chemical Compositions, Fatty Acid, Collagen and Cholesterol Contents of Thai Hybrid Native and Broiler Chicken Meats
}

\author{
Kanok-Orn Intarapichet ${ }^{1}$, Wisittiporn Suksombat ${ }^{2}$ and Bussayarat Maikhunthod ${ }^{1}$ \\ ${ }^{1}$ School of Food Technology, Institute of Agricultural Technology, Suranaree University of Technology, \\ Nakhon Ratchasima 30000, Thailand \\ ${ }^{2}$ School of Animal Production, Institute of Agricultural Technology, Suranaree University of Technology, \\ Nakhon Ratchasima 30000, Thailand
}

\begin{abstract}
Trails were conducted to determine chemical compositions of 4-lines and 5-lines cross Thai hybrid native chicken meats and skins as compared to those of commercial broiler at the market weight of $1.8 \mathrm{~kg}$. Protein of breasts, skins $(P<0.01)$ and thighs $(P<0.05)$ of hybrid native chickens were higher than those of broilers. Broiler and 5-lines cross chicken thighs had similar fat contents and higher $(P<0.05)$ than those of 4 -lines cross breed. Broiler breasts contained higher $(P<0.01)$ cholesterol, while their skins contained lower amounts $(P<0.01)$ than those of hybrid native chickens. The hybrid native chicken breasts and thighs contained almost twice higher collagen than those of broilers. In regard to sexes, proximate compositions of both sexes of the 5-lines cross chickens were in similar trends to those of broilers. Female breasts and thighs contained higher saturated and monounsaturated fatty acids than those of males $(P<0.01)$. The meats and skins of male chickens contained higher polyunsaturated fatty acids and cholesterol than those of females $(P<0.01)$. Both sexes of the 4-lines cross chickens contained higher total collagen compared with broilers and 5-lines cross $(P<0.01)$. In addition, it could be concluded that the meats of both Thai hybrid native chickens contained lower cholesterol and higher collagen than that of broiler chicken.
\end{abstract}

Key words: Cholesterol, Collagen, Fatty acids, Thai hybrid native chickens

J. Poult. Sci., 45: 7-14, 2008

\section{Introduction}

Poultry production in Thailand has been increased in the past 20 years. Species of chickens have been genetically developed for commercialization. Thai hybrid native chickens are the cross breeds of Thai male indigenous fighting cocks and female broilers. In general, they are the so-called Gai Baan Thai, meaning Thai domestic chickens. Among Thai consumers, the meat of the Thai hybrid native chickens is more preferable and recognized as lean, tasty, not so tough and chewy, and has higher economic values compared to commercial broiler meats. To promote Gai Baan Thai as a commercial product for exporting, the Livestock Development Department and the Exporting Promotion Department have been working closely with the Thailand Research Fund to develop new hybrid breeds with higher meat quality.

Although numerous studies on breeding selection, methods of raising, dietary and growth performance, and body com-

Received: May 16, 2007, Acepted: August 17, 2007

Correspondence: Dr. K.-O. Intarapichet, School of Food Technology, Institute of Agricultural Technology, Suranaree University of Technology, Nakhon Ratchasima 30000, Thailand.

(E-mail: ikanok-orn@sut.ac.th) position of the Thai native chickens have been widely conducted (Ratanasetakul et al., 1987, Bansidhi et al., 1988, Theerapanturat et al., 1988, Choprakarn et al., 1998b, Chotesangasa, 2001; Bunchasak and Kittichonnthawat, 2003) including Thai indigenous hens and their egg characteristics (Choprakarn et al., 1998a), little is known on differences of carcass and nutrient composition of meat of these chickens. To gain quality information for effective marketing of these chicken meats, it is necessary to know their chemical compositions. The aims of the present work were to evaluate the main qualities of commercial Thai hybrid native chicken meats, namely proximate compositions, fatty acid, cholesterol and collagen content, with respect to breeds, sexes at the preferable market weight of $1.8 \mathrm{~kg}$, and to compare them with those of commercial broiler meats at the same weight.

\section{Materials and Methods}

\section{Source of animals}

A total of 90 chickens, 15 each of males and females, at the market weight of $1.8 \mathrm{~kg}$ were investigated including 4lines cross breed, 5-lines cross breed and commercial broilers. The 4-lines (Bar Plymouth Rock $\times$ Rhode Ireland Red $\times$ Shianghai $\times$ Thai indigenous) and 5-lines (Bar Plymouth Rock $\times$ Rhode Ireland Red $\times$ Shianghai $\times$ Aus- 
tralian game black $\times$ Thai indigenous) cross breed chickens were randomly obtained from two different commercial poultry farms in the central region of Thailand. The commercial broilers (Hubbard) were obtained from a local commercial farm in Nakhon Ratchasima Province. All chickens were fed ad libitum with commercial formula feed in 2 stages, i.e. for grower (0-3 weeks) with 3,200 $\mathrm{kcal} / \mathrm{kg}$ metabolizable energy and $23.0 \%$ concentrated protein (CP) and for finisher (4 weeks up) with 3,200 $\mathrm{kcal} / \mathrm{kg}$ and $21.0 \% \mathrm{CP}$.

The animals were transferred to the Suranaree University of Technology Farm. After resting at a minimum of $6 \mathrm{~h}$ without feeding, the animals were slaughtered and dressed according to the method described by Henrickson (1978) and Jaturasittha (2000). The carcasses were cooled in ice cold water till the body temperature dropped down to $8^{\circ} \mathrm{C}$ then, hung in a cold room at $4 \pm 1^{\circ} \mathrm{C}$ for $30 \mathrm{~min}$, weighed and kept in the cold room for $24 \mathrm{~h}$.

The carcasses were cut and separated into portions of drumsticks, thighs, breasts and wings. All portions were weighed and deboned. Boneless breasts, thighs and skin were used for chemical analyses.

Breast, thigh meat and skin of 5 chickens each of both male and female were randomly sampled, minced using a domestic meat chopper (Moulinex 327, Spain) then vacuum packed and stored at $-20^{\circ} \mathrm{C}$ until used.

\section{Proximate analysis}

All chemical compositions were analyzed on fresh ground samples. Moisture, ash and protein contents were determined according to AOAC (1997) methods. The moisture content was determined by oven-drying at $105^{\circ} \mathrm{C}$ for $24 \mathrm{~h}$. The ash content was determined by ashing at $600^{\circ} \mathrm{C}$ in a muffle furnace (Carbolite, England) for $6 \mathrm{~h}$ or until light gray or white ash was obtained. Total protein $(\mathrm{N} \times 6.25)$ content was determined by the Kjeldahl method.

Fat content was determined according to the rapid modified Babcock method (AOAC, 1997) with slight modification. Ground meat of $9 \mathrm{~g}$ for breast and thigh meat and $4.5 \mathrm{~g}$ for skin were used for analysis. Percent fat content was read directly from Paley bottle. The multiplying factor of 2 was used for the skin sample.

\section{Fatty acid analysis}

Lipid was extracted from the fresh ground sample using Folch et al. (1957) and Metcalfe et al. (1966) methods with slight modification. Sample (15 g) was homogenized (Nissei AM-8 Homogenizer, Nihonseiki Kaisha, Ltd., Japan) with $90 \mathrm{ml}$ of chloroform-methanol $(2: 1 \mathrm{~V} / \mathrm{V})$ solution for $2 \mathrm{~min}$. The homogenate was filtered into a separating funnel. Then $30 \mathrm{ml}$ of chloroform, $30 \mathrm{ml}$ of deionized water and $5 \mathrm{ml}$ of $0.58 \% \mathrm{NaCl}$ were added to the filtrate, shaken and allowed to separate. The chloroform layer was transferred to a weighed evaporating flask and evaporated at $40^{\circ} \mathrm{C}$ in a rotary evaporator (BUCHI Rotavapor R-200, BUCHI Labortechnik AG, Switzerland). Fatty acid methyl esters (FAMEs) were prepared by transmethylation using $14 \%$ boron trifluoride in methanol.
The FAMEs were analyzed using a Hewlett Packard gas chromatograph (GC) with autoinjection (HEWLET PACKARD, HP 6890 Series GC system, USA) equipped with a $100 \mathrm{~m} \times 0.25 \mathrm{~mm} \times 0.20 \mu \mathrm{m}$ fused silica capillary column (SP 2560, Supelco Inc, Bellefonte, PA, USA) and flame ionization detector (FID). Injector and detector temperatures were at $260^{\circ} \mathrm{C}$. The initial column temperature was at $70^{\circ} \mathrm{C}$ then, increased at $13^{\circ} \mathrm{C} / \mathrm{min}$ to $175^{\circ} \mathrm{C}$ and $4^{\circ} \mathrm{C} / \mathrm{min}$ to $240^{\circ} \mathrm{C}$. Carrier gas was helium with the flow rate of $1 \mathrm{ml} / \mathrm{min}$. An aliquot of $1 \mu \mathrm{l}$ of the FAME was injected with the split ratio of 1:30. Identification and percentages of fatty acids were made by comparing the relative retention times of FAME peaks from sample with standards (37 component FAME Mix, catalog No. 47885U, Supelco, Bellefonte, PA, USA).

\section{Cholesterol analysis}

Extraction and quantification of cholesterol were carried out by the method of Rowe et al. (1999) with slight modification. A sample of $5 \mathrm{~g}$ was placed in a flat bottom flask. An equivalent amount of $4 \mathrm{ml} / \mathrm{g}$ sample of ethanol-methanol-isopropanol (90:5:5 v/v/v) and $1 \mathrm{ml} / \mathrm{g}$ sample of $60 \% \mathrm{KOH}$ were added to the sample and refluxed for $1 \mathrm{~h}$. After cooling the digest to room temperature, $100 \mathrm{ml}$ of hexane and $25 \mathrm{ml}$ of deionized water were added, stirred and let stand till separation occurred. An aliquot of 12.5 $\mathrm{m} l$ of hexane layer was transferred to a flask and evaporated to dryness with nitrogen. The residue was dissolved with $1 \mathrm{ml}$ of hexane containing $0.1 \mathrm{mg} / \mathrm{ml}$ of $5 \alpha$-cholestane (Sigma, St. Louise, MO, USA) as an internal standard and transferred to a sample vial. An aliquot of $1 \mu l$ was injected, with the split ratio of 1:100, into the GC (HEWLET PACKARD, HP 6890 Series GC system, USA) equipped with an HP 19091A-112 column $(25 \mathrm{~m} \times$ $0.32 \mathrm{~mm} \times 0.52 \mu \mathrm{m}$ fused silica capillary column) and FID. Injector and detector temperatures were at 260 and $300^{\circ} \mathrm{C}$, respectively. Separation was carried out isocratically at $300^{\circ} \mathrm{C}$ with helium gas flow rate of $1 \mathrm{ml} / \mathrm{min}$. Cholesterol identification was made by comparing the relative retention time peak of the sample with pure cholesterol (Fluka, Riedel-deHaën, Germany).

\section{Collagen content}

Soluble and insoluble collagen was determined according to the method of Woessner (1961), and Bailey and Light (1989). Finely minced meat was weighed (6g) into a centrifuge tube, $20 \mathrm{ml}$ of deionized water was added, mixed and put in a $80^{\circ} \mathrm{C}$ water bath for $30 \mathrm{~min}$. The tube was cooled and homogenized for $20 \mathrm{~s}$ then, centrifuged at $2,000 \times \mathrm{g}$ for $15 \mathrm{~min}$, filtered into a $100 \mathrm{ml}$ volumetric flask. To the supernatant, $30 \mathrm{ml} 6 \mathrm{M} \mathrm{HCl}$ was added. The sediment was transferred to a $250 \mathrm{~m} l$ flask and mixed with $50 \mathrm{ml} 6 \mathrm{M} \mathrm{HCl}$. The samples were placed in a sand bath at $150^{\circ} \mathrm{C}$ overnight. After hydrolysis, the samples were adjusted to the volume with deionized water and filtered. An aliquot of $10 \mathrm{~m} l$ filtrate was transferred to a $50 \mathrm{ml}$ flask, adjusted $\mathrm{pH}$ to 6 with $1 \mathrm{~N} \mathrm{NaOH}$ then, adjusted to the volume with deionized water. A $2 \mathrm{ml}$ portion of sample solution was mixed with $1 \mathrm{~m} l$ oxidizing agent $(0.79 \mathrm{~g}$ chlo- 
ramin $T$ in $5 \mathrm{ml}$ deionized water and mixed with $45 \mathrm{ml}$ citrate-acetate buffer, $\mathrm{pH} \mathrm{6)}$ and kept for $20 \mathrm{~min}$. After adding $1 \mathrm{ml}$ of color reagent (4g 4-dimethylaminobenzaldehyde in $20 \mathrm{~m} l$ propanol and mixed with $9 \mathrm{ml}$ of $60 \%$ perchloric acid), the sample was incubated at $60^{\circ} \mathrm{C}$ for 15 min, cooled for $5 \mathrm{~min}$ and let stand for $25 \mathrm{~min}$ then, the absorbance of hydroxyproline was measured at $560 \mathrm{~nm}$. Collagen contents were calculated from the calibration curve of pure hydroxyproline and multiplied by the factor of 7.25 .

\section{Statistical analysis}

Statistical analysis was evaluated by factorial in completely randomized design (CRD) with statistical analysis system (SAS, 1993). Statistic comparison was done between breeds and sexes of the chickens within breast, thigh and skin, separately. Collagen contents were compared only in breast and thigh meat groups. Each animal was taken as a replicate. Chemical analysis of each replicate was performed in triplicate samples. Analysis of variance was analyzed and comparison of means was done by Duncan's Multiple Range Test.

\section{Results and Discussion}

\section{Chemical component comparison among breeds of chickens} Proximate composition

The proximate composition of the chicken meats and skins from each breed is presented in Table 1. Among meat of all breeds, the moisture contents was not different except for the skins of the native chickens were significantly higher $(P<0.01)$ than those of the broilers. It was obvious that the moisture contents of these 3 chicken breed meats were similar to the values reported for other economic birds such as ostrich and emu (Sales et al., 1996;

Table 1. Proximate composition (\%) of Thai native and commercial broiler meats and skins

\begin{tabular}{cccc}
\hline \hline Component & Breast & Thigh & Skin \\
\hline Moisture & & & \\
K & $74.9 \pm 1.25$ & $75.2 \pm 0.89$ & $56.4 \pm 4.93^{\mathrm{a} * *}$ \\
T & $74.7 \pm 0.68$ & $73.7 \pm 2.58$ & $51.4 \pm 12.19^{\mathrm{a}}$ \\
B & $75.2 \pm 1.49$ & $73.9 \pm 2.65$ & $36.4 \pm 7.27^{\mathrm{b}}$ \\
Protein & & & \\
K & $22.2 \pm 1.27^{\mathrm{ad} * *}$ & $20.0 \pm 1.23^{\mathrm{a} *}$ & $22.1 \pm 2.50^{\mathrm{a} * *}$ \\
T & $23.0 \pm 0.96^{\mathrm{a}}$ & $19.8 \pm 1.35^{\mathrm{a}}$ & $17.0 \pm 4.06^{\mathrm{b}}$ \\
B & $21.1 \pm 1.50^{\mathrm{b}}$ & $18.6 \pm 1.35^{\mathrm{b}}$ & $11.4 \pm 2.42^{\mathrm{c}}$ \\
Fat & & & \\
K & $2.4 \pm 0.63^{\mathrm{ad} *}$ & $3.4 \pm 0.75^{\mathrm{b} *}$ & $20.6 \pm 5.62^{\mathrm{c} * *}$ \\
T & $2.9 \pm 0.75^{\mathrm{a}}$ & $5.2 \pm 2.34^{\mathrm{a}}$ & $34.0 \pm 17.61^{\mathrm{b}}$ \\
B & $2.0 \pm 0.84^{\mathrm{b}}$ & $5.3 \pm 3.13^{\mathrm{a}}$ & $57.6 \pm 9.83^{\mathrm{a}}$ \\
Ash & & & \\
K & $1.1 \pm 0.06^{\mathrm{c} * *}$ & $1.0 \pm 0.05$ & $0.7 \pm 0.07^{\mathrm{a} * *}$ \\
T & $1.1 \pm 0.02^{\mathrm{b}}$ & $1.1 \pm 0.05$ & $0.6 \pm 0.13^{\mathrm{b}}$ \\
B & $1.2 \pm 0.04^{\mathrm{a}}$ & $1.1 \pm 0.06$ & $0.5 \pm 0.13^{\mathrm{b}}$ \\
\hline
\end{tabular}

$*=$ significant difference $(P<0.05), * *=$ highly significant difference $(P<0.01)$.

Means with different letter are significantly different in the same column.

$\mathrm{K}=$ 4-lines cross, $\mathrm{T}=5$-lines cross, $\mathrm{B}=$ Broiler.
Berge et al., 1997) and for Thai indigenous and broiler chickens (Wattanachant et al., 2004). However, Piironen et al. (2002) reported moisture content of thigh and leg of chickens obtained from retail stores in Finland had the average moisture of only $69.5 \%$. Although there were no significant differences among breeds, moisture contents of the 5-lines cross breed chickens were relatively closer to those of broilers. This could be due to the 5-lines cross breed having more commercial broiler blood than 4-lines cross chicken.

Both native chickens had similar amounts of protein in their meats but the skins of the 4-lines cross breed were higher $(P<0.01)$ compared with those of the 5 -lines cross. Overall, the breasts $(P<0.01)$, thighs $(P<0.05)$ and skins $(P<0.01)$ of both native hybrid chickens contained higher amounts of protein compared with those of broilers. This could be due to the fact that native chickens normally have a slower growth rate and are older than broilers of the same weight (Choprakarn et al., 1998a). Berge et al. (1997) reported that protein contents of the bird increased with animal age. However, in this study, protein contents of the meats of these three chicken breeds were in the same ranges reported by Wattanachant et al. (2004) and Trindade et al. (2004) for Thai indigenous, broiler and layer hen, and Piironen et al. (2002) for chicken consumed in Finland.

Different fat contents of meats and skins $(P<0.05$ and $P<0.01$, respectively) were observed among breeds of chickens with the thigh and skin of broiler having higher fat than those of native chickens but the broiler breast had lower fat content than those of native chickens. The amounts of fat contents of the 5-lines cross were lined closer to those of broiler chickens. This could suggest that the 5-lines cross chickens had the closer characteristics to the broiler due to more cross breeding with commercial broilers. Fat contents of leg and thigh of chicken meats were reported (Piironen et al., 2002) having higher amounts compared with those of breasts which similar to the results of this work.

Differences $(P<0.01)$ of ash contents were found among breeds of chickens only in the breasts and skins but not in the thighs. The breasts of both native chickens contained lower ash compared with those of broilers. However, ash contents of all chicken meats were similar to those reported by Foegeding and Lanier (1996) and Trindade et al. (2004).

Overall, chicken meat compositions were similar to those reported by Foegeding and Lamier (1996). But data for chicken skins could not be found in any references. Fatty acid composition, cholesterol and collagen content

Saturated fatty acids (SFA) of meats and skins of all chicken breeds were not significantly different $(P>0.05)$ (Table 2) and in the same range of layer hens reported by Trindade et al. (2004). Different monounsaturated fatty acids (MUFA) of the breasts were not found among chicken breeds. The thighs and skins of the 4-lines cross breed contained lower $(P<0.01)$ MUFA compared with 
Table 2. Fatty acid, cholesterol and collagen of Thai hybrid native and commercial broiler

\begin{tabular}{|c|c|c|c|}
\hline Component & Breast & Thigh & Skin \\
\hline \multicolumn{4}{|c|}{ Saturated fatty acid ( $\%$ of total fatty acids) } \\
\hline $\mathrm{K}$ & $31.6 \pm 2.37$ & $30.7 \pm 2.14$ & $30.6 \pm 1.79$ \\
\hline $\mathrm{T}$ & $30.7 \pm 1.37$ & $30.4 \pm 1.60$ & $30.8 \pm 1.34$ \\
\hline B & $28.3 \pm 7.38$ & $30.7 \pm 3.11$ & $30.9 \pm 3.28$ \\
\hline \multicolumn{4}{|c|}{ Monounsaturated fatty acid ( $\%$ of total fatty acids) } \\
\hline $\mathrm{K}$ & $26.5 \pm 2.05$ & $32.0 \pm 2.03^{\mathrm{b} * *}$ & $35.9 \pm 1.21^{\mathrm{b} * *}$ \\
\hline $\mathrm{T}$ & $28.0 \pm 4.67$ & $36.6 \pm 3.49^{\mathrm{a}}$ & $38.9 \pm 2.33^{\mathrm{a}}$ \\
\hline B & $31.5 \pm 7.48$ & $36.8 \pm 1.30^{\mathrm{a}}$ & $39.3 \pm 1.10^{\mathrm{a}}$ \\
\hline \multicolumn{4}{|c|}{ Polyunsaturated fatty acid ( $\%$ of total fatty acids) } \\
\hline $\mathrm{K}$ & $41.9 \pm 3.80$ & $37.3 \pm 2.73^{\mathrm{a} * *}$ & $33.4 \pm 1.52^{\mathrm{a} * *}$ \\
\hline $\mathrm{T}$ & $41.2 \pm 5.57$ & $33.0 \pm 4.85^{\mathrm{b}}$ & $30.1 \pm 3.13^{\mathrm{b}}$ \\
\hline B & $40.2 \pm 3.71$ & $32.5 \pm 3.33^{\mathrm{b}}$ & $29.8 \pm 3.16^{\mathrm{b}}$ \\
\hline \multicolumn{4}{|c|}{ Cholesterol (mg/100g) } \\
\hline $\mathrm{K}$ & $43.6 \pm 5.06^{\mathrm{b} * *}$ & $72.7 \pm 6.14$ & $136.6 \pm 18.79^{a * *}$ \\
\hline $\mathrm{T}$ & $45.8 \pm 3.81^{\mathrm{b}}$ & $74.8 \pm 6.33$ & $91.3 \pm 29.76^{\mathrm{b}}$ \\
\hline B & $53.2 \pm 2.88^{\mathrm{a}}$ & $76.1 \pm 2.85$ & $82.0 \pm 11.46^{\mathrm{b}}$ \\
\hline \multicolumn{4}{|c|}{ Soluble collagen $(\mathrm{mg} / \mathrm{g})$} \\
\hline $\mathrm{K}$ & $1.5 \pm 0.43^{\mathrm{a} * *}$ & $1.7 \pm 1.04$ & na \\
\hline $\mathrm{T}$ & $1.4 \pm 0.32^{\mathrm{a}}$ & $1.6 \pm 0.43$ & na \\
\hline $\mathrm{B}$ & $0.9 \pm 0.37^{\mathrm{b}}$ & $1.7 \pm 0.93$ & na \\
\hline \multicolumn{4}{|c|}{ Insoluble collagen $(\mathrm{mg} / \mathrm{g})$} \\
\hline $\mathrm{K}$ & $5.5 \pm 3.64^{a * *}$ & $11.7 \pm 4.51^{\mathrm{a} * *}$ & na \\
\hline $\mathrm{T}$ & $3.1 \pm 0.51^{\mathrm{b}}$ & $10.7 \pm 3.43^{\mathrm{a}}$ & na \\
\hline B & $2.3 \pm 0.64^{\mathrm{b}}$ & $5.9 \pm 1.39^{\mathrm{b}}$ & na \\
\hline \multicolumn{4}{|c|}{ Total collagen $(\mathrm{mg} / \mathrm{g})$} \\
\hline $\mathrm{K}$ & $7.0 \pm 4.03^{\mathrm{a} * *}$ & $13.4 \pm 5.13^{\mathrm{a} * *}$ & na \\
\hline $\mathrm{T}$ & $4.5 \pm 0.63^{\mathrm{b}}$ & $12.3 \pm 3.54^{\mathrm{a}}$ & na \\
\hline B & $3.2 \pm 0.87^{\mathrm{b}}$ & $7.5 \pm 2.11^{\mathrm{b}}$ & na \\
\hline
\end{tabular}

$*=$ significant difference $(P<0.05), * *=$ highly significant difference $(P<0.01)$, na $=$ not analyzed.

Means with different letter are significantly different in the same column.

$\mathrm{K}=$ 4-lines cross, $\mathrm{T}=5$-lines cross, $\mathrm{B}=$ Broiler.

those of the 5-lines cross breed and broiler which contained similar amounts for both thighs and skins. Polyunsaturated fatty acids (PUFA) of the thighs and skins of all chicken breeds were also different $(P<0.01)$ but not for the breasts. In contrast to the MUFA contents, the thighs and skins of the 4-lines cross breed contained the highest PUFA while those of the 5-lines cross breed were closer to broilers. The SFA of all chickens in this study were lower than those reported by Wattanachant el al. (2004) for Thai indigenous chicken and commercial broiler. However, the amounts of PUFA were higher than those reported by this group. This could be due to the differences of lipids in the diets of the birds. In addition, the meat of all chicken breeds also had PUFA to SFA (P:S) ratio well above 1.00 (data not shown) as recommended value should be above 0.4 in order to prevent implication in the diseases associated to meat consumption (Wood et al., 2003).

One of the major health concerns of the consumers in eating animal products is cholesterol content. Cholesterol contents of breasts and skins differed $(P<0.01)$ among breeds of chickens. Even difference was not found for thigh meat $(P>0.05)$. Broiler meat contained slightly higher cholesterol (Table 2). The breast of both native chicken breeds contained similar amounts of cholesterol $(P>0.01)$ and lower $(P<0.01)$ than those of broiler $(53.2$ $\mathrm{mg} / 100 \mathrm{~g})$. In contrast, broiler skin contained the least amounts of cholesterol which was not different $(P>0.01)$ from those of the 5 -lines cross breed $(91.3 \mathrm{mg} / 100 \mathrm{~g})$ but different $(P<0.01)$ from those of the 4-lines cross breed. Cholesterol contents of both meat types of all breeds were well within the values reported 50.10 to $71.12 \mathrm{mg} / 100 \mathrm{~g}$ of different cuts of ostrich (Sales et al., 1996; Horbañczuk et al., 1998; Sales, 1998: Girolami et al., 2003) and 56.20 to $81.00 \mathrm{mg} / 100 \mathrm{~g}$ of chicken meats (Chizzolini et al., 1999; Piironen et al., 2002).

Greater amounts of all types of collagen were obtained in the meats of both hybrid native breeds as shown in Table 2 with those of the 4-lines cross breed being the highest. It is generally agreed that collagen is one of the factors affecting tenderness of meat, particularly insoluble and total collagen and higher collagen content is found in older animals (Purslow, 2005) and in thigh muscles at the same age (Moran 1999). Insoluble and total collagen contents of the 5-lines cross and broiler breasts did not differ while differences $(P<0.01)$ were found between the thighs of both hybrid native cross breeds and broiler. With higher amounts of collagen contents, it is suggested that the meats of the Thai hybrid native chickens are less tender compared with those of commercial broilers. At the same live weight, the native chicken is older than broiler since the native chicken has lower growth rate (Choprakarn et al., 1998a). Therefore, it could be one of the reasons why the native cross breeds contained greater amount of collagen. However, being chewy but not so tough is the preferable characteristic of the Thai native chickens among the Thai consumers.

Chemical component comparison between sexes within and among breeds of chickens

Proximate composition

Table 3 presents comparison data of the proximate compositions of both sexes of chickens among breeds. The moisture contents of breasts of both sexes of all chicken breeds did not differ $(P>0.05)$. The thighs and skins of both sexes among breeds were significantly different $(P<$ 0.01) with the males of all breeds containing higher amounts of moisture compared with those of females. Lawrie (1998) presented similar results, muscle of male animals contained higher moisture contents.

The protein contents of both sexes among breeds were different with $P<0.05$ for breasts and thighs, and $P<0.01$ for skins. However, protein contents of the breasts between sexes of each breed were not different and similar results obtained for thighs of the 5-lines cross and broiler except for those of the 4-lines cross chicken of which the female was higher. No differences of protein content between sexes of animals were also reported by Lawrie (1998). In this study, male skins of all breeds had higher protein than females. 
Table 3. Proximate composition of chicken meat and skin between sexes, within and among breeds

\begin{tabular}{cccc}
\hline \hline Component & \multicolumn{1}{c}{ Breast } & Thigh & Skin \\
\hline Moisture $(\%)$ & & & \\
K-M & $74.9 \pm 1.61$ & $75.7 \pm 0.75^{\mathrm{a} * *}$ & $55.8 \pm 4.26^{\mathrm{a} * *}$ \\
K-F & $75.0 \pm 0.98$ & $74.7 \pm 0.84^{\mathrm{a}}$ & $56.9 \pm 5.98^{\mathrm{a}}$ \\
T-M & $75.1 \pm 0.53$ & $75.7 \pm 0.81^{\mathrm{a}}$ & $61.9 \pm 6.27^{\mathrm{a}}$ \\
T-F & $74.2 \pm 0.52$ & $71.6 \pm 1.91^{\mathrm{b}}$ & $40.8 \pm 4.21^{\mathrm{b}}$ \\
B-M & $75.5 \pm 0.63$ & $75.4 \pm 1.63^{\mathrm{a}}$ & $38.2 \pm 4.40^{\mathrm{b}}$ \\
B-F & $74.9 \pm 2.09$ & $72.3 \pm 2.65^{\mathrm{b}}$ & $34.6 \pm 9.56^{\mathrm{b}}$ \\
Protein $(\%)$ & & & \\
K-M & $22.7 \pm 1.10^{\mathrm{ad} *}$ & $19.2 \pm 0.88^{\mathrm{bc} *}$ & $24.1 \pm 1.21^{\mathrm{a} * *}$ \\
K-F & $21.6 \pm 1.30^{\mathrm{bc}}$ & $20.9 \pm 0.85^{\mathrm{a}}$ & $20.1 \pm 1.71^{\mathrm{b}}$ \\
T-M & $22.5 \pm 1.20^{\mathrm{ad}}$ & $20.3 \pm 1.60^{\mathrm{ad}}$ & $20.6 \pm 1.27^{\mathrm{b}}$ \\
T-F & $23.5 \pm 0.30^{\mathrm{a}}$ & $19.4 \pm 1.00^{\mathrm{abc}}$ & $13.4 \pm 1.86^{\mathrm{c}}$ \\
B-M & $20.6 \pm 1.59^{\mathrm{c}}$ & $19.2 \pm 1.53^{\mathrm{bc}}$ & $12.6 \pm 2.29^{\mathrm{c}}$ \\
B-F & $21.5 \pm 1.38^{\mathrm{bc}}$ & $18.0 \pm 0.95^{\mathrm{c}}$ & $10.1 \pm 2.02^{\mathrm{d}}$ \\
Fat $(\%)$ & & & \\
K-M & $2.6 \pm 0.55^{\mathrm{a} *}$ & $3.4 \pm 0.96^{\mathrm{b} * *}$ & $16.6 \pm 4.22^{\mathrm{c} * *}$ \\
K-F & $2.1 \pm 0.65^{\mathrm{ad}}$ & $3.3 \pm 0.57^{\mathrm{b}}$ & $24.6 \pm 3.65^{\mathrm{c}}$ \\
T-M & $2.9 \pm 0.74^{\mathrm{a}}$ & $3.4 \pm 0.22^{\mathrm{b}}$ & $18.6 \pm 3.58^{\mathrm{c}}$ \\
T-F & $2.8 \pm 0.84^{\mathrm{a}}$ & $7.1 \pm 1.99^{\mathrm{a}}$ & $49.4 \pm 9.58^{\mathrm{b}}$ \\
B-M & $1.4 \pm 0.26^{\mathrm{b}}$ & $3.5 \pm 1.22^{\mathrm{b}}$ & $52.8 \pm 6.46^{\mathrm{b}}$ \\
B-F & $2.6 \pm 0.82^{\mathrm{a}}$ & $7.0 \pm 3.59^{\mathrm{a}}$ & $62.4 \pm 10.88^{\mathrm{a}}$ \\
Ash $(\%)$ & & & \\
K-M & $1.1 \pm 0.08^{\mathrm{cd} * *}$ & $1.1 \pm 0.06$ & $0.71 \pm 0.08^{\mathrm{a} * *}$ \\
K-F & $1.1 \pm 0.04^{\mathrm{d}}$ & $1.0 \pm 0.04$ & $0.75 \pm 0.05^{\mathrm{a}}$ \\
T-M & $1.1 \pm 0.02^{\mathrm{bc}}$ & $1.1 \pm 0.06$ & $0.68 \pm 0.06^{\mathrm{a}}$ \\
T-F & $1.2 \pm 0.02^{\mathrm{b}}$ & $1.1 \pm 0.02$ & $0.47 \pm 0.09^{\mathrm{b}}$ \\
B-M & $1.2 \pm 0.03^{\mathrm{ad}}$ & $1.1 \pm 0.06$ & $0.51 \pm 0.07^{\mathrm{b}}$ \\
B-F & $1.2 \pm 0.02^{\mathrm{a}}$ & $1.1 \pm 0.06$ & $0.51 \pm 0.08^{\mathrm{b}}$ \\
\hline & & & \\
\hline
\end{tabular}

$*=$ significant difference $(P<0.05), * *=$ highly significant difference $(P<0.01)$.

Means with different letter are significantly different in the same column.

$\mathrm{K}=$ 4-lines cross, $\mathrm{T}=5$-lines cross, $\mathrm{B}=$ Broiler, $\mathrm{M}=$ Male, $\mathrm{F}=$ Female.

Different fat contents were observed in breasts $(P<$ $0.05)$, thighs $(P<0.01)$ and skins $(P<0.01)$ between sexes among breed of chickens. However, differences were not found in the breasts of male and female native chickens, but the breasts of female broilers contained higher fat than those of males. Different fat contents were observed between sexes of the 5-lines cross and broilers in thighs and skins i.e., female chickens contained higher than males. De Marchi et al. (2005) also reported that breast of female Padovana chicken contained higher fat than male. In general, males contain less intramuscular fat than females (Lawrie, 1998).

Except for skins of the 5-lines cross breed, the ash contents of breasts, thighs and skins of male and female chickens were not different but when compared between sexes among breeds, differences were found $(P<0.01)$ in the breasts and skins.

\section{Fatty acid composition, cholesterol and collagen content}

Comparison of amounts of fatty acid groups, cholesterol and collagen between sexes of the chickens and among breeds are presented in Table 4. Different $(P<0.01)$ SFA contents were observed between sexes and among breeds
Table 4. Fatty acid, cholesterol and collagen content of chicken meats and skins between sexes, within and among breeds

\begin{tabular}{|c|c|c|c|}
\hline Component & Breast & Thigh & Skin \\
\hline \multicolumn{4}{|c|}{ Saturated fatty acid ( $\%$ of total fatty acids) } \\
\hline K-M & $30.9 \pm 1.31^{\mathrm{a} * *}$ & $31.8 \pm 2.45^{\mathrm{a} * *}$ & $30.7 \pm 1.18^{\mathrm{b} * *}$ \\
\hline $\mathrm{K}-\mathrm{F}$ & $32.4 \pm 3.06^{\mathrm{a}}$ & $29.6 \pm 1.11^{\mathrm{b}}$ & $30.6 \pm 1.32^{\mathrm{b}}$ \\
\hline $\mathrm{T}-\mathrm{M}$ & $29.9 \pm 0.51^{\mathrm{a}}$ & $29.2 \pm 0.67^{\mathrm{b}}$ & $30.2 \pm 0.47^{\mathrm{b}}$ \\
\hline $\mathrm{T}-\mathrm{F}$ & $31.7 \pm 1.41^{\mathrm{a}}$ & $31.6 \pm 1.35^{\mathrm{a}}$ & $31.8 \pm 1.45^{\mathrm{b}}$ \\
\hline $\mathrm{B}-\mathrm{M}$ & $23.0 \pm 7.22^{\mathrm{b}}$ & $27.9 \pm 0.66^{\mathrm{b}}$ & $28.0 \pm 0.42^{\mathrm{c}}$ \\
\hline B-F & $33.6 \pm 0.94^{\mathrm{a}}$ & $33.5 \pm 1.40^{\mathrm{a}}$ & $33.9 \pm 1.59^{\mathrm{a}}$ \\
\hline \multicolumn{4}{|c|}{ Monounsaturated fatty acid ( $\%$ of total fatty acids) } \\
\hline K-M & $25.2 \pm 2.05$ & $31.8 \pm 1.53^{\mathrm{c} * *}$ & $36.2 \pm 1.18^{\mathrm{c} * *}$ \\
\hline $\mathrm{K}-\mathrm{F}$ & $27.9 \pm 0.90$ & $32.3 \pm 2.59^{c}$ & $35.7 \pm 1.32^{\mathrm{c}}$ \\
\hline $\mathrm{T}-\mathrm{M}$ & $24.7 \pm 2.52$ & $33.6 \pm 1.04^{\mathrm{c}}$ & $37.0 \pm 0.47^{\mathrm{c}}$ \\
\hline $\mathrm{T}-\mathrm{F}$ & $31.4 \pm 3.73$ & $39.7 \pm 1.70^{\mathrm{a}}$ & $40.9 \pm 1.45^{\mathrm{a}}$ \\
\hline B-M & $30.5 \pm 10.94$ & $36.7 \pm 0.90^{\mathrm{b}}$ & $39.4 \pm 0.42^{\mathrm{b}}$ \\
\hline B-F & $32.5 \pm 1.89$ & $37.0 \pm 1.71^{\mathrm{b}}$ & $39.2 \pm 1.59^{\mathrm{b}}$ \\
\hline \multicolumn{4}{|c|}{ Polyunsaturated fatty acid ( $\%$ of total fatty acids) } \\
\hline K-M & $44.0 \pm 2.82^{\mathrm{ad} * *}$ & $36.4 \pm 3.07^{a * *}$ & $33.1 \pm 1.58^{\mathrm{a} * *}$ \\
\hline $\mathrm{K}-\mathrm{F}$ & $39.8 \pm 3.67^{\text {ad }}$ & $38.1 \pm 2.35^{\mathrm{a}}$ & $33.7 \pm 1.56^{\mathrm{a}}$ \\
\hline $\mathrm{T}-\mathrm{M}$ & $45.5 \pm 2.88^{\mathrm{a}}$ & $37.2 \pm 1.35^{\mathrm{a}}$ & $32.9 \pm 0.60^{\mathrm{a}}$ \\
\hline $\mathrm{T}-\mathrm{F}$ & $37.0 \pm 3.98^{\mathrm{ad}}$ & $28.7 \pm 2.48^{b}$ & $27.3 \pm 1.55^{\mathrm{b}}$ \\
\hline B-M & $46.5 \pm 17.80^{\mathrm{a}}$ & $35.4 \pm 0.76^{\mathrm{a}}$ & $32.6 \pm 0.83^{\mathrm{a}}$ \\
\hline B-F & $33.9 \pm 2.65^{\mathrm{b}}$ & $29.6 \pm 1.66^{\mathrm{b}}$ & $27.0 \pm 1.34^{\mathrm{b}}$ \\
\hline \multicolumn{4}{|c|}{ Cholesterol $(\mathrm{mg} / 100 \mathrm{~g})$} \\
\hline K-M & $45.8 \pm 3.31^{\mathrm{bc} * *}$ & $73.3 \pm 3.65$ & $132.2 \pm 8.0^{\mathrm{ad} * *}$ \\
\hline $\mathrm{K}-\mathrm{F}$ & $41.5 \pm 5.91^{\mathrm{c}}$ & $72.0 \pm 8.40$ & $141.0 \pm 26.1^{\mathrm{a}}$ \\
\hline T-M & $47.0 \pm 2.74^{\mathrm{b}}$ & $78.8 \pm 3.70$ & $115.3 \pm 15.7^{\mathrm{b}}$ \\
\hline $\mathrm{T}-\mathrm{F}$ & $44.6 \pm 4.67^{\mathrm{bc}}$ & $70.9 \pm 6.18$ & $67.4 \pm 17.7^{\mathrm{c}}$ \\
\hline B-M & $54.3 \pm 2.35^{\mathrm{a}}$ & $76.4 \pm 3.47$ & $86.3 \pm 12.9^{c}$ \\
\hline B-F & $52.1 \pm 3.18^{\mathrm{a}}$ & $75.8 \pm 2.44$ & $77.6 \pm 9.1^{\mathrm{c}}$ \\
\hline \multicolumn{4}{|c|}{ Soluble collagen $(\mathrm{mg} / \mathrm{g})$} \\
\hline K-M & $1.8 \pm 0.42^{\mathrm{a} * *}$ & $2.0 \pm 0.84$ & na \\
\hline $\mathrm{K}-\mathrm{F}$ & $1.2 \pm 0.15^{\mathrm{bc}}$ & $1.5 \pm 1.23$ & na \\
\hline $\mathrm{T}-\mathrm{M}$ & $1.3 \pm 0.40^{\mathrm{bc}}$ & $1.4 \pm 1.43$ & na \\
\hline $\mathrm{T}-\mathrm{F}$ & $1.5 \pm 0.22^{\mathrm{ad}}$ & $1.8 \pm 1.78$ & na \\
\hline B-M & $1.0 \pm 0.43^{\mathrm{c}}$ & $2.3 \pm 2.26$ & na \\
\hline B-F & $0.8 \pm 0.33^{\mathrm{c}}$ & $1.1 \pm 1.07$ & na \\
\hline \multicolumn{4}{|c|}{ Insoluble collagen $(\mathrm{mg} / \mathrm{g})$} \\
\hline K-M & $7.67 \pm 4.19^{\mathrm{a} * *}$ & $11.2 \pm 4.41^{\mathrm{ad} *}$ & na \\
\hline $\mathrm{K}-\mathrm{F}$ & $3.37 \pm 0.90^{\mathrm{b}}$ & $12.2 \pm 5.06^{\mathrm{a}}$ & na \\
\hline $\mathrm{T}-\mathrm{M}$ & $2.98 \pm 0.50^{\mathrm{b}}$ & $11.0 \pm 4.58^{\mathrm{ad}}$ & na \\
\hline $\mathrm{T}-\mathrm{F}$ & $3.25 \pm 0.53^{\mathrm{b}}$ & $10.5 \pm 2.32^{\mathrm{ad}}$ & na \\
\hline B-M & $2.79 \pm 0.49^{\mathrm{b}}$ & $6.6 \pm 1.41^{\mathrm{c}}$ & na \\
\hline B-F & $1.79 \pm 0.24^{\mathrm{b}}$ & $5.1 \pm 0.91^{\mathrm{bc}}$ & na \\
\hline \multicolumn{4}{|c|}{ Total collagen $(\mathrm{mg} / \mathrm{g})$} \\
\hline K-M & $9.5 \pm 4.58^{\mathrm{a} * *}$ & $13.2 \pm 5.07^{\mathrm{a} *}$ & na \\
\hline $\mathrm{K}-\mathrm{F}$ & $4.6 \pm 0.82^{\mathrm{b}}$ & $13.6 \pm 5.78^{a}$ & na \\
\hline T-M & $4.3 \pm 0.65^{\mathrm{b}}$ & $12.4 \pm 4.54^{\mathrm{a}}$ & na \\
\hline $\mathrm{T}-\mathrm{F}$ & $4.7 \pm 0.57^{b}$ & $12.3 \pm 2.73^{\mathrm{a}}$ & na \\
\hline B-M & $3.8 \pm 0.76^{\mathrm{b}}$ & $8.9 \pm 2.03^{\mathrm{b}}$ & na \\
\hline B-F & $2.6 \pm 0.51^{\mathrm{b}}$ & $6.2 \pm 1.07^{\mathrm{ad}}$ & na \\
\hline
\end{tabular}

$*=$ significant difference $(P<0.05), * *=$ highly significant difference $(P<0.01)$, na $=$ not analyzed.

Means with different letter are significantly different in the same column.

$\mathrm{K}=$ 4-lines cross, $\mathrm{T}=5$-lines cross, $\mathrm{B}=$ Broiler, $\mathrm{M}=$ Male, $\mathrm{F}=$ Female.

of chickens. However, the breasts and skins of both sexes of the native chickens contained similar amounts of SFA but the thighs of female 5-lines cross breed and broiler 
Table 5. Fatty acid profile ( $\%$ of total fatty acids) of chicken meats and skins between sexes and among breeds

\begin{tabular}{|c|c|c|c|c|}
\hline Fatty acid & & Breast & Thigh & Skin \\
\hline \multirow[t]{6}{*}{$\mathrm{C} 14: 0$} & $\mathrm{~K}-\mathrm{M}$ & $0.43 \pm 0.09$ & $0.62 \pm 0.07^{\mathrm{c} * *}$ & $0.75 \pm 0.06^{\mathrm{b} * *}$ \\
\hline & $\mathrm{K}-\mathrm{F}$ & $0.39 \pm 0.02$ & $0.58 \pm 0.04^{\mathrm{c}}$ & $0.70 \pm 0.03^{\mathrm{bc}}$ \\
\hline & T-M & $0.45 \pm 0.07$ & $0.79 \pm 0.06^{\mathrm{b}}$ & $0.99 \pm 0.03^{\mathrm{a}}$ \\
\hline & $\mathrm{T}-\mathrm{F}$ & $0.64 \pm 0.11$ & $0.90 \pm 0.07^{\mathrm{a}}$ & $0.96 \pm 0.04^{\mathrm{a}}$ \\
\hline & B-M & $1.71 \pm 2.90$ & $0.46 \pm 0.03^{\mathrm{d}}$ & $0.52 \pm 0.02^{\mathrm{d}}$ \\
\hline & B-F & $0.42 \pm 0.05$ & $0.58 \pm 0.04^{\mathrm{c}}$ & $0.65 \pm 0.05^{\mathrm{c}}$ \\
\hline \multirow[t]{6}{*}{$\mathrm{C} 16: 0$} & $\mathrm{~K}-\mathrm{M}$ & $21.25 \pm 0.98^{\mathrm{c} * *}$ & $21.36 \pm 1.58^{\mathrm{b} * *}$ & $22.00 \pm 1.46^{\mathrm{c} * *}$ \\
\hline & $\mathrm{K}-\mathrm{F}$ & $21.51 \pm 1.25^{\mathrm{bc}}$ & $19.46 \pm 0.87^{\mathrm{b}}$ & $20.79 \pm 0.72^{\mathrm{c}}$ \\
\hline & T-M & $1.14 \pm 0.30^{\mathrm{c}}$ & $20.56 \pm 0.44^{b}$ & $21.72 \pm 0.68^{c}$ \\
\hline & $\mathrm{T}-\mathrm{F}$ & $23.42 \pm 1.49^{\mathrm{ad}}$ & $23.84 \pm 1.69^{\mathrm{a}}$ & $24.18 \pm 1.32^{\mathrm{b}}$ \\
\hline & B-M & $21.98 \pm 0.73^{\mathrm{bc}}$ & $21.05 \pm 0.34^{\mathrm{b}}$ & $22.03 \pm 0.49^{c}$ \\
\hline & B-F & $24.54 \pm 1.09^{\mathrm{a}}$ & $25.58 \pm 0.73^{\mathrm{a}}$ & $26.71 \pm 0.79^{\mathrm{a}}$ \\
\hline \multirow[t]{6}{*}{$\mathrm{C} 17: 0$} & K-M & $0.21 \pm 0.02^{\mathrm{n}}$ & $0.25 \pm 0.02^{\mathrm{a} * *}$ & $0.32 \pm 0.07^{\mathrm{ad} * *}$ \\
\hline & $\mathrm{K}-\mathrm{F}$ & $0.24 \pm 0.03$ & $0.26 \pm 0.04^{\mathrm{a}}$ & $0.38 \pm 0.10^{\mathrm{a}}$ \\
\hline & T-M & $0.17 \pm 0.09$ & $0.24 \pm 0.01^{\mathrm{a}}$ & $0.31 \pm 0.03^{\mathrm{ad}}$ \\
\hline & $\mathrm{T}-\mathrm{F}$ & $0.16 \pm 0.02$ & $0.18 \pm 0.02^{\mathrm{b}}$ & $0.22 \pm 0.05^{\mathrm{b}}$ \\
\hline & B-M & $0.44 \pm 0.71$ & $0.10 \pm 0.02^{\mathrm{c}}$ & $0.10 \pm 0.01^{\mathrm{c}}$ \\
\hline & B-F & nd & $0.10 \pm 0.02^{\mathrm{c}}$ & $0.12 \pm 0.01^{\mathrm{c}}$ \\
\hline \multirow[t]{6}{*}{$\mathrm{C} 18: 0$} & K-M & $8.60 \pm 0.32^{\mathrm{a} * *}$ & $9.12 \pm 1.17^{a * *}$ & $7.15 \pm 0.49^{\mathrm{ad} * *}$ \\
\hline & $\mathrm{K}-\mathrm{F}$ & $9.83 \pm 1.80^{\mathrm{a}}$ & $8.89 \pm 1.44^{\mathrm{a}}$ & $8.16 \pm 1.62^{\mathrm{a}}$ \\
\hline & T-M & $7.78 \pm 0.13^{\mathrm{a}}$ & $7.00 \pm 0.95^{\mathrm{b}}$ & $6.38 \pm 0.75^{\mathrm{bc}}$ \\
\hline & $\mathrm{T}-\mathrm{F}$ & $7.19 \pm 0.53^{\mathrm{a}}$ & $6.23 \pm 0.51^{\mathrm{b}}$ & $5.77 \pm 0.43^{\mathrm{bc}}$ \\
\hline & B-M & $3.36 \pm 3.73^{\mathrm{b}}$ & $6.16 \pm 0.65^{b}$ & $5.06 \pm 0.33^{\mathrm{c}}$ \\
\hline & B-F & $8.16 \pm 0.27^{\mathrm{a}}$ & $6.91 \pm 0.87^{\mathrm{b}}$ & $6.16 \pm 0.79^{\mathrm{bc}}$ \\
\hline \multirow[t]{6}{*}{$\mathrm{C} 20: 0$} & $\mathrm{~K}-\mathrm{M}$ & $0.26 \pm 0.07$ & $0.31 \pm 0.05^{a * *}$ & $0.31 \pm 0.05^{\mathrm{ad} * *}$ \\
\hline & $\mathrm{K}-\mathrm{F}$ & $0.18 \pm 0.02$ & $0.24 \pm 0.04^{\mathrm{b}}$ & $0.35 \pm 0.12^{\mathrm{a}}$ \\
\hline & T-M & $0.16 \pm 0.01$ & $0.18 \pm 0.02^{\mathrm{bc}}$ & $0.22 \pm 0.01^{\mathrm{bc}}$ \\
\hline & $\mathrm{T}-\mathrm{F}$ & $0.12 \pm 0.01$ & $0.16 \pm 0.03^{\mathrm{c}}$ & $0.13 \pm 0.03^{c}$ \\
\hline & B-M & $0.47 \pm 0.72$ & $0.13 \pm 0.01^{\mathrm{c}}$ & $0.15 \pm 0.02^{\mathrm{c}}$ \\
\hline & B-F & $0.17 \pm 0.02$ & $0.15 \pm 0.02^{\mathrm{c}}$ & $0.15 \pm 0.01^{\mathrm{c}}$ \\
\hline \multirow[t]{6}{*}{$\mathrm{C} 22: 0$} & $\mathrm{~K}-\mathrm{M}$ & $0.09 \pm 0.01$ & $0.09 \pm 0.03^{\mathrm{n}}$ & $0.06 \pm 0.04^{\mathrm{n}}$ \\
\hline & $\mathrm{K}-\mathrm{F}$ & $0.10 \pm 0.02$ & $0.08 \pm 0.02$ & $0.09 \pm 0.01$ \\
\hline & T-M & $0.10 \pm 0.01$ & $0.09 \pm 0.02$ & $0.06 \pm 0.01$ \\
\hline & $\mathrm{T}-\mathrm{F}$ & $0.08 \pm 0.02$ & $0.10 \pm 0.03$ & $0.04 \pm 0.01$ \\
\hline & B-M & $0.24 \pm 0.33$ & $0.06 \pm 0.01$ & $0.06 \pm 0.03$ \\
\hline & B-F & $0.19 \pm 0.03$ & $0.08 \pm 0.02$ & $0.05 \pm 0.01$ \\
\hline \multirow[t]{6}{*}{$\mathrm{C} 16: 1$} & $\mathrm{~K}-\mathrm{M}$ & $0.81 \pm 0.25^{\mathrm{c} * *}$ & $1.70 \pm 0.50^{\mathrm{b} * *}$ & $1.89 \pm 0.39^{\mathrm{b} * *}$ \\
\hline & $\mathrm{K}-\mathrm{F}$ & $0.71 \pm 0.24^{\mathrm{c}}$ & $1.39 \pm 0.66^{\mathrm{b}}$ & $1.19 \pm 0.38^{\mathrm{b}}$ \\
\hline & T-M & $0.76 \pm 0.18^{c}$ & $1.77 \pm 0.28^{\mathrm{b}}$ & $1.63 \pm 0.22^{\mathrm{b}}$ \\
\hline & $\mathrm{T}-\mathrm{F}$ & $2.22 \pm 0.64^{\mathrm{b}}$ & $3.89 \pm 0.35^{\mathrm{a}}$ & $3.91 \pm 0.71^{\mathrm{a}}$ \\
\hline & B-M & $3.25 \pm 0.52^{\mathrm{a}}$ & $3.75 \pm 0.48^{\mathrm{a}}$ & $4.09 \pm 0.33^{\mathrm{a}}$ \\
\hline & B-F & $3.06 \pm 0.41^{\mathrm{a}}$ & $3.43 \pm 0.43^{\mathrm{a}}$ & $3.63 \pm 0.48^{\mathrm{a}}$ \\
\hline \multirow[t]{6}{*}{$\mathrm{C} 18 \mathrm{~s} \ln 9 \mathrm{c}$} & K-M & $23.55 \pm 2.02^{\mathrm{c} * *}$ & $29.64 \pm 1.11^{\mathrm{d} * *}$ & $33.82 \pm 1.06^{\mathrm{b} * *}$ \\
\hline & $\mathrm{K}-\mathrm{F}$ & $26.09 \pm 0.80^{\mathrm{bc}}$ & $30.22 \pm 2.01^{\mathrm{cd}}$ & $34.06 \pm 1.01^{\mathrm{b}}$ \\
\hline & T-M & $23.25 \pm 2.15^{\mathrm{c}}$ & $31.35 \pm 0.78^{\mathrm{bcd}}$ & $34.81 \pm 0.27^{\mathrm{b}}$ \\
\hline & $\mathrm{T}-\mathrm{F}$ & $28.37 \pm 3.27^{\mathrm{ad}}$ & $35.47 \pm 1.38^{\mathrm{a}}$ & $36.72 \pm 0.89^{\mathrm{a}}$ \\
\hline & B-M & $31.46 \pm 0.81^{\mathrm{a}}$ & $32.54 \pm 0.97^{\mathrm{bc}}$ & $34.86 \pm 0.68^{\mathrm{b}}$ \\
\hline & B-F & $28.67 \pm 1.66^{\mathrm{ad}}$ & $33.21 \pm 1.48^{\mathrm{ad}}$ & $35.17 \pm 1.18^{\mathrm{ad}}$ \\
\hline \multirow[t]{6}{*}{ C20:1 } & $\mathrm{K}-\mathrm{M}$ & $0.31 \pm 0.08^{\mathrm{b} *}$ & $0.35 \pm 0.19^{\mathrm{ad} *}$ & $0.47 \pm 0.07^{\mathrm{a} * *}$ \\
\hline & $\mathrm{K}-\mathrm{F}$ & $0.27 \pm 0.02^{\mathrm{a}}$ & $0.43 \pm 0.02^{\mathrm{a}}$ & $0.46 \pm 0.07^{\mathrm{a}}$ \\
\hline & T-M & $0.21 \pm 0.02^{\mathrm{b}}$ & $0.37 \pm 0.05^{\mathrm{ad}}$ & $0.47 \pm 0.16^{\mathrm{a}}$ \\
\hline & $\mathrm{T}-\mathrm{F}$ & $0.22 \pm 0.05^{\mathrm{b}}$ & $0.29 \pm 0.05^{\mathrm{b}}$ & $0.29 \pm 0.03^{\mathrm{b}}$ \\
\hline & B-M & $1.19 \pm 2.00^{\mathrm{b}}$ & $0.29 \pm 0.02^{\mathrm{b}}$ & $0.29 \pm 0.02^{\mathrm{b}}$ \\
\hline & B-F & $0.33 \pm 0.06^{\mathrm{b}}$ & $0.27 \pm 0.02^{\mathrm{b}}$ & $0.26 \pm 0.03^{\mathrm{b}}$ \\
\hline \multirow[t]{6}{*}{$\mathrm{C} 18 \mathrm{a} 2 \mathrm{n} 6 \mathrm{c}$} & K-M & $22.99 \pm 1.62$ & $29.58 \pm 0.92^{\mathrm{a} * *}$ & $30.62 \pm 1.55^{\mathrm{a} * *}$ \\
\hline & $\mathrm{K}-\mathrm{F}$ & $22.40 \pm 0.64$ & $29.03 \pm 1.78^{\mathrm{a}}$ & $31.55 \pm 1.70^{\mathrm{a}}$ \\
\hline & T-M & $21.57 \pm 0.79$ & $28.27 \pm 0.76^{\mathrm{a}}$ & $30.21 \pm 0.36^{\mathrm{a}}$ \\
\hline & $\mathrm{T}-\mathrm{F}$ & $21.11 \pm 1.23$ & $24.31 \pm 1.01^{\mathrm{b}}$ & $24.85 \pm 1.51^{\mathrm{b}}$ \\
\hline & B-M & $22.28 \pm 12.11$ & $28.78 \pm 1.01^{\mathrm{a}}$ & $29.34 \pm 0.79^{\mathrm{a}}$ \\
\hline & B-F & $21.94 \pm 0.66$ & $24.64 \pm 1.32^{\mathrm{b}}$ & $24.34 \pm 1.24^{\mathrm{b}}$ \\
\hline
\end{tabular}

Table 5. (Continuation) Fatty acid profile ( $\%$ of total fatty acids) of chicken meats and skins between sexes and among breeds

\begin{tabular}{|c|c|c|c|c|}
\hline Fatty acid & & Breast & Thigh & Skin \\
\hline \multirow[t]{6}{*}{ C18:3n3 } & $\mathrm{K}-\mathrm{M}$ & $0.47 \pm 0.07$ & $0.76 \pm 0.04^{\mathrm{d} * *}$ & $0.88 \pm 0.07^{\mathrm{d} * *}$ \\
\hline & $\mathrm{K}-\mathrm{F}$ & $0.45 \pm 0.07$ & $0.70 \pm 0.12^{\mathrm{d}}$ & $0.85 \pm 0.12^{\mathrm{d}}$ \\
\hline & T-M & $0.47 \pm 0.07$ & $0.84 \pm 0.06^{\mathrm{cd}}$ & $1.04 \pm 0.04^{\mathrm{c}}$ \\
\hline & $\mathrm{T}-\mathrm{F}$ & $0.67 \pm 0.10$ & $0.97 \pm 0.06^{\mathrm{c}}$ & $1.08 \pm 0.03^{\mathrm{c}}$ \\
\hline & B-M & $6.62 \pm 0.08$ & $1.87 \pm 0.12^{\mathrm{a}}$ & $2.11 \pm 0.07^{\mathrm{a}}$ \\
\hline & B-F & $0.92 \pm 0.07$ & $1.56 \pm 0.11^{\mathrm{b}}$ & $1.67 \pm 0.07^{\mathrm{b}}$ \\
\hline \multirow[t]{6}{*}{$\mathrm{C} 20: 2$} & K-M & $0.48 \pm 0.08$ & $0.46 \pm 0.06^{a * *}$ & $0.41 \pm 0.23^{\mathrm{a} *}$ \\
\hline & $\mathrm{K}-\mathrm{F}$ & $0.43 \pm 0.04$ & $0.38 \pm 0.06^{\mathrm{ad}}$ & $0.30 \pm 0.05^{\mathrm{abc}}$ \\
\hline & T-M & $0.50 \pm 0.07$ & $0.43 \pm 0.02^{\mathrm{a}}$ & $0.34 \pm 0.02^{\mathrm{ad}}$ \\
\hline & $\mathrm{T}-\mathrm{F}$ & $0.34 \pm 0.04$ & $0.29 \pm 0.02^{\mathrm{b}}$ & $0.25 \pm 0.02^{\mathrm{bc}}$ \\
\hline & B-M & $2.13 \pm 3.52$ & $0.36 \pm 008^{\mathrm{ad}}$ & $0.25 \pm 0.02^{\mathrm{bc}}$ \\
\hline & B-F & $0.65 \pm 0.23$ & $0.29 \pm 0.03^{\mathrm{b}}$ & $0.19 \pm 0.04^{c}$ \\
\hline \multirow[t]{6}{*}{ C20:3n6 } & K-M & $0.56 \pm 0.10$ & $0.36 \pm 0.02^{\mathrm{abc} *}$ & $0.18 \pm 0.02^{\mathrm{ad} *}$ \\
\hline & $\mathrm{K}-\mathrm{F}$ & $0.46 \pm 0.17$ & $0.28 \pm 0.05^{\mathrm{c}}$ & $0.15 \pm 0.03^{\mathrm{b}}$ \\
\hline & T-M & $0.75 \pm 0.21$ & $0.32 \pm 0.06^{\mathrm{bc}}$ & $0.16 \pm 0.03^{\mathrm{b}}$ \\
\hline & $\mathrm{T}-\mathrm{F}$ & $0.71 \pm 0.16$ & $0.26 \pm 0.05^{\mathrm{c}}$ & $0.18 \pm 0.02^{\mathrm{ad}}$ \\
\hline & B-M & $2.71 \pm 4.24$ & $0.43 \pm 0.09^{\mathrm{a}}$ & $0.22 \pm 0.04^{\mathrm{a}}$ \\
\hline & B-F & $1.37 \pm 0.31$ & $0.39 \pm 0.14^{\mathrm{ad}}$ & $0.17 \pm 0.03^{\text {ad }}$ \\
\hline \multirow[t]{6}{*}{$\mathrm{C} 20: 4 \mathrm{n} 6$} & K-M & $10.50 \pm 2.05^{\mathrm{ad} * *}$ & $4.32 \pm 0.64^{\mathrm{n}}$ & $0.68 \pm 0.04^{\mathrm{ad} * *}$ \\
\hline & $\mathrm{K}-\mathrm{F}$ & $4.33 \pm 5.54^{\mathrm{c}}$ & $4.85 \pm 1.87$ & $0.73 \pm 0.27^{\mathrm{a}}$ \\
\hline & T-M & $11.03 \pm 1.74^{\mathrm{a}}$ & $4.09 \pm 0.87$ & $0.68 \pm 0.16^{\mathrm{ad}}$ \\
\hline & $\mathrm{T}-\mathrm{F}$ & $6.40 \pm 2.06^{\mathrm{abc}}$ & $1.59 \pm 1.09$ & $0.47 \pm 0.10^{\mathrm{abc}}$ \\
\hline & B-M & $5.36 \pm 1.56^{\mathrm{bc}}$ & $2.67 \pm 0.68$ & $0.44 \pm 0.09^{\mathrm{bc}}$ \\
\hline & B-F & $6.09 \pm 1.24^{\mathrm{abc}}$ & $1.83 \pm 0.87$ & $0.33 \pm 0.07^{c}$ \\
\hline \multirow{6}{*}{$\begin{array}{l}\text { C20:5n3 } \\
\text { (EPA) }\end{array}$} & K-M & $0.33 \pm 0.11$ & $0.15 \pm 0.03^{\mathrm{n}}$ & nd \\
\hline & $\mathrm{K}-\mathrm{F}$ & $0.23 \pm 0.08$ & 0.08 & nd \\
\hline & T-M & $0.39 \pm 0.12$ & nd & nd \\
\hline & $\mathrm{T}-\mathrm{F}$ & $0.48 \pm 0.19$ & $0.16 \pm 0.00$ & nd \\
\hline & B-M & $1.17 \pm 1.71$ & $0.13 \pm 0.06$ & nd \\
\hline & B-F & $0.42 \pm 0.10$ & $0.14 \pm 0.05$ & nd \\
\hline \multirow{6}{*}{$\begin{array}{l}\text { C22:6n3 } \\
\text { (DHA) }\end{array}$} & $\mathrm{K}-\mathrm{M}$ & $8.47 \pm 1.41^{\mathrm{ad} * *}$ & $3.26 \pm 1.02^{a * *}$ & $0.22 \pm 0.05^{\mathrm{n}}$ \\
\hline & $\mathrm{K}-\mathrm{F}$ & $11.34 \pm 2.57^{\mathrm{a}}$ & $2.78 \pm 0.94^{\mathrm{a}}$ & $0.22 \pm 0.04$ \\
\hline & T-M & $10.31 \pm 1.17^{\mathrm{a}}$ & $2.91 \pm 0.44^{\mathrm{a}}$ & $0.29 \pm 0.07$ \\
\hline & $\mathrm{T}-\mathrm{F}$ & $6.92 \pm 2.41^{\mathrm{ad}}$ & $1.19 \pm 0.74^{\mathrm{b}}$ & $0.32 \pm 0.06$ \\
\hline & B-M & $5.53 \pm 8.90^{\mathrm{ad}}$ & $0.69 \pm 0.17^{b}$ & nd \\
\hline & B-F & $1.43 \pm 0.35^{\mathrm{b}}$ & $0.34 \pm 0.13^{b}$ & nd \\
\hline
\end{tabular}

$*=$ significant difference $(P<0.05), * *=$ highly significant difference $(P<0.01), \mathrm{n}=$ not statistically compared, $\mathrm{nd}=$ not detected .

Means with different letter are significantly different in the same column.

$\mathrm{K}=$ 4-lines cross, $\mathrm{T}=5$-lines cross, $\mathrm{B}=$ Broiler, $\mathrm{M}=$ Male, $\mathrm{F}=$ Female.

contained higher SFA than those of the 4-lines cross breed chickens. Different $(P>0.05)$ MUFA contents of the breasts were not found between sexes within and among breeds of chickens while differences $(P<0.01)$ were found in the thighs and skins. However, in all types of samples, the female chickens contained higher amounts of MUFA than the males. On the contrary, the PUFA contents of female breasts and thighs were less than those of males. Different $(P<0.01)$ PUFA contents between sexes within breed of chickens were found in the thighs and skins of the 5-lines cross breed and broiler and in the breast of broiler.

Table 4 presents interesting results that the meats and skins of male chickens of all breeds studied obviously contained higher amounts of cholesterol. However, differences of cholesterol $(P<0.01)$ between sexes within breeds were found only in the skins of the 5-lines cross breed 
chickens while those of male and female breasts within each breed did not differ. In general, cholesterol contents were highest in chicken skin of all breeds. Moran (1999) also reported that a large portion of fat including cholesterol was in chicken skin.

Collagen content, sex and age of animals are the important factors affecting toughness of animal meat (Liu et al., 1996; Warriss, 2000). Different $(P<0.01)$ contents of all types of collagen in the breasts were observed between sexes within and among chicken breeds. Results in Table 4 showed that in all types of samples, those of male chickens contained higher collagen of which the 4-lines cross breed was the highest in all types of collagen. Both male and female broilers contained the least amounts of collagen of which the 5-lines cross breed was in between the other two breeds. Collagen content of chicken thigh becomes higher and less soluble when the animal is more mature (Moran, 1999; Warriss, 2000). Therefore, these results suggest that the Thai hybrid native chickens, particularly the 4-lines cross breed chickens produced the toughest meat of all breeds studied.

\section{Fatty acid profiles}

The averages of fatty acid profiles of the breasts, thighs and skins of both sexes of all types of chickens are listed in Table 5. Fatty acid composition of meats and skins of all types of chickens ranged from $\mathrm{C} 12: 0$ to $\mathrm{C} 22: 6 \mathrm{n} 3$ with minute amounts of C12:0, C15:0, C17:1, C24:1, C18:3n6, C20:3n3 (data not shown), C22:0, C20:4n6, C20:5n3 (EPA) and $\mathrm{C} 22: 6 \mathrm{n} 3$ (DHA) were found in some samples. Some differences $(P<0.01$ and $<0.05)$ in fatty acid profiles were observed between sexes and among breeds of chickens. Palmitic acid (C16:0) was the major SFA, followed by stearic acid (C18:0). Wattanachant et al. (2004) and De Marchi et al. (2005) also reported that C16:0 was higher than C18:0 in Thai indigenous and Padovana chickens, respectively. The females of all chicken types contained higher amounts of C16:0 than males which was similar trend to C18:0 for both hybrid chickens. On the contrary, the male broilers contained higher amounts of C18:0.

The C18:1n9c fatty acid was the majority of the MUFA of which females were higher than those of males in all sample types except for broiler breasts. Differences $(P<$ 0.01) of PUFAs were also found between sexes and among chicken breeds with $\mathrm{C} 18: 2 \mathrm{n} 6 \mathrm{c}$ being the most abundant. It appeared that the male chickens contained higher amounts of C18:2n6c. The second most abundant PUFA was arachidonic acid (C20:4n6) which was higher in male breasts of both native hybrid chickens $(P<0.01)$ but lower in male breasts of broilers. This fatty acid was found in some thigh samples of the male 4-lines cross breed and found in small amounts in chicken skins. Eicosapentaenoic acid (EPA) and docosahexaenoic acid (DHA) were also found in small amounts but not in all sample types. In general, oleic acid was the main fatty acid in both meat and skin fat, followed by palmitic acid and linoleic acid. This pattern was consistent with that reported by De Marchi et al. (2005) for Padovana chicken and
Wattanachant et al. (2004) for Thai indigenous and broiler chickens.

In summary, chemical compositions of the 5-lines cross breed chicken were in between the 4-lines cross breed and commercial broiler and relatively closer to commercial broilers. The meats of both Thai hybrid native chickens contained lower cholesterol and higher collagen than broiler chicken. Regarding sexes of the chickens, the female chickens contained higher SFA and MUFA than males. In contrast, the male chickens contained higher PUFA and cholesterol than females.

\section{Acknowledgments}

This work was supported by The Thailand Research Fund, Bangkok and Suranaree University of Technology, Nakhon Ratchasima, Thailand.

\section{References}

AOAC. Official methods of analysis, 16th Ed. Association of Analytical Chemists, Washington, D.C. 1997.

Bailey AJ and Light ND. Connective tissue in meat and meat products. Elsevier Applied Science, London. 1989.

Bansidhi K, Bansidhi D, Siwapraphakorn A, Chaiput S, Sakiya P and Sirikachonpan S. A study of protein and energy requirements of native chicken in Northeast Thailand. Research and Development Institute, Khon Kaen University, Khon Kaen, Thailand. 1988. (in Thai).

Berge P, Lepetit J, Renerre M and Touraille C. Meat quality traits in the emu (Dromaius novaehollandiae) as affected by muscle type and animal age. Meat Science, 45: 209-221. 1997.

Bunchasak C and Kittichonnthawat S. A comparison on growth performance, chemical body composition and thyroid hormone of Thai native and Shamo chicks. Kamphangsaen Academic Journal, 1: 77-84. 2003. (in Thai).

Chizzolini R, Zanardi E, Dorigoni V and Ghidini S. Calorific value and cholesterol content of normal and low fat meat and meat products. Trends in Food Science \& Technology, 10: 119-128. 1999.

Choprakarn K, Salangam I and Tanaka K. Laying performance, egg characteristics and egg composition in Thai indigenous hens. Journal of National Research Council Thailand, 30: 117. 1998a.

Choprakarn K, Wattanakul W, Wongpichet K and Suriyachantratong, W. Development of Thai indigenous chickens and cross bred of Thai indigenous chicken production: A review of the literature. Technical report submitted to Thailand Research Fund. National Research Council Thailand. 1998b.

Chotesangasa R. Effects of mating ratio, cock number in the flock and breeder age on fertility in Thai native chicken flock. Kasetsart Journal (Natural Science), 35: 122-131. 2001.

De Marchi M, Cassandro M, Lunardi E, Baldan G and Siegel PB. Carcass characteristics and qualitative meat traits of the Padovana breed of chicken. International Journal of Poultry Science, 4: 233-238. 2005.

Foegeding EA and Lanier TC. Characteristics of edible muscle tissues. In: Food Chemistry. 3 rd. ed., (Fennema OR ed.) pp. 879-942, Marcel Dekker, Inc, New York. 1996.

Folch J, Lees M and Stanley GHS. A simple method for the 
isolation and purification of total lipids from animal tissues. Journal of Biological Chemistry, 226: 467-509. 1957.

Girolami A, Marsico I, D'andrea G, Braghieri A, Napolitano F and Cifuni GF. Fatty acid profile, cholesterol content and tenderness of ostrich meat as influenced by age at slaughter and muscle type. Meat Science, 64: 309-315. 2003.

Henrickson RL. Meat, poultry, and seafood technology. PrenticeHall, Inc. New Jersey. 1978.

Horbañczuk J, Sales J, Celeda T, Konecka A, Ziêba G and Kawka P. Cholesterol content and fatty acid composition of ostrich meat as influenced by subspecies. Meat Science, 50: 385-388. 1998.

Jaturasittha S. Meat Technology. Department of Animal Science, Chiangmai University. Chiangmai. 2000. (in Thai).

Lawrie RA. Lawrie's Meat Science. 6th. Ed. Technomic Publishing Co. Inc. Lancaster. 1998.

Liu A, Nishimura T and Takahashi K. Relationship between structural properties of intramuscular connective tissue and toughness of various chicken skeletal muscles. Meat Science, 43: 43-49. 1996.

Metcalfe LD, Schmitz AA and Pelka JR. Rapid preparation of fatty acid ester from lipids for gas chromatographic analysis. Analytical Chemistry, 38: 514-515. 1966.

Moran ET. Live production factors influencing yield and quality of poultry meat. In: Poultry Meat Science, (Richardson RI and Mead GC eds.) pp. 179-195, CABI Publishing. Wallingford. 1999.

Piironen V, Toivo J and Lampi A-M. New data for cholesterol contents in meat, fish, milk, eggs and their products consumed in Finland. Journal of Food composition and Analysis, 15: 705-713. 2002.

Purslow PP. Intramuscular connective tissue and its role in meat quality-a review. Meat Science, 70: 435-447. 2005.

Ratanasetakul C, Laopaiboon B, Udomseing P and Chitpraneechai S. Improvement of native chickens in the urban area:
Technical Report. Faculty of Agriculture, Khon Kaen University. Khon Kaen, Thailand. 1987. (in Thai).

Rowe A, Macedo FAF, Visentainer JV, Souza NE and Matsushita M. Muscle composition and fatty aid profile in lambs fattened in drylot or pasture. Meat Science, 51: 283-288. 1999.

Sales J. Fatty acid composition and cholesterol content of different ostrich muscles. Meat Science, 49: 489-492. 1998.

Sales J, Marais D and Kruger M. Fat content, caloric value, cholesterol content, and fatty acid composition of raw and cooked ostrich meat. Journal of Food Composition and Analysis, 9: 85-89. 1996.

SAS. SAS 6.08.04 WIN. SAS Institute Inc., Carry, NC. 1993.

Theerapanturat S, Sripraya $P$ and Chaiput S. Effect of protein on carcass quality of native chickens. In: Proceedings of the 2 th Seminar on Thai indigenous chickens. Northeastern Regional Office of Agriculture (pp. 87-96), Tha Pra, Khon Kaen, Thailand. 1988. (in Thai).

Trindade MA, De Felicio PE and Castillo CJC. Mechanically separated meat of broiler breeder and white layer spent hens. Science Agriculture (Piracicaba, Brazil), 61: 234-239. 2004.

Warriss PD. The chemical composition and structure of meat. In: Meat Science: An Introductory Text, pp. 37-68, CABI Publishing, Wallingford. 2000.

Wattanachant S, Benjakul S. and Ledward DA. Composition, color, and texture of Thai indigenous and broiler chicken muscles. Poultry Science, 83: 123-128. 2004.

Woessner AJ. The determination of hydroxyproline in tissue and protein samples containing small proportions of this amino acid. Archives of Biochemistry and Biophysics, 93: 440-447. 1961.

Wood JD, Richardson RI, Nute G., Fisher AV, Campo MM, Kasapidou E, Sheard PR and Enser M. Effects of fatty acids on meat quality: a review. Meat Science, 66: 21-32. 2003. 